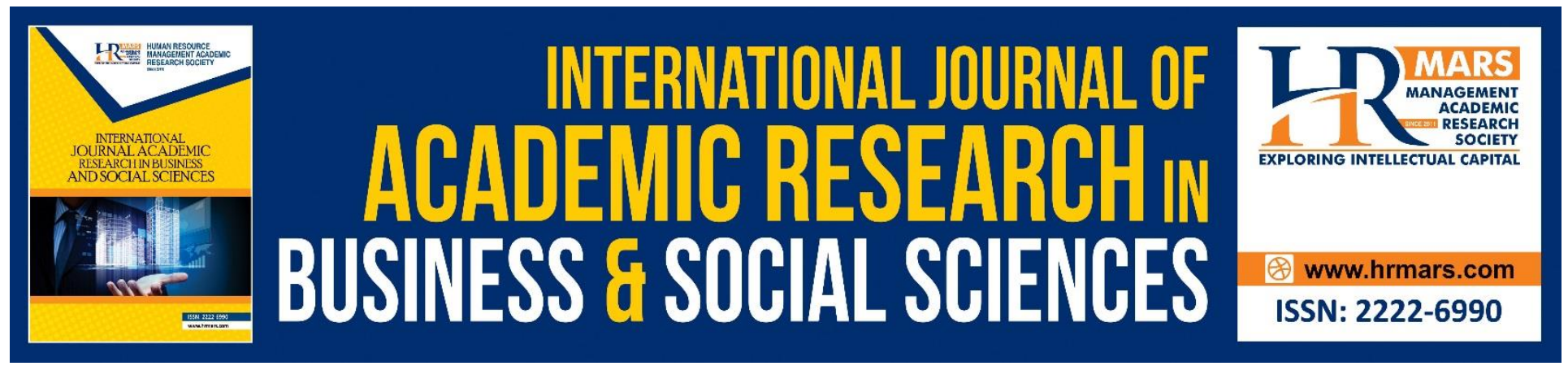

\title{
Factors Stimulating Students to Venture into The Field of Entrepreneurship Towards Producing Entrepreneurs Among University Students
}

\author{
Muhammad Bazlan Mustafa
}

To Link this Article: http://dx.doi.org/10.6007/IJARBSS/v9-i3/5752

DOI: $10.6007 /$ IJARBSS/v9-i3/5752

Received: 21 Jan 2019, Revised: 26 Feb 2019, Accepted: 20 March 2019

Published Online: 23 March 2019

In-Text Citation: (Mustafa, 2019)

To Cite this Article: Mustafa, M. B. (2019). Factors Stimulating Students to Venture into The Field of Entrepreneurship Towards Producing Entrepreneurs Among University Students. International Journal of Academic Research in Business and Social Sciences, 9(3), 875-883.

\section{Copyright: (C) 2019 The Author(s)}

Published by Human Resource Management Academic Research Society (www.hrmars.com)

This article is published under the Creative Commons Attribution (CC BY 4.0) license. Anyone may reproduce, distribute, translate and create derivative works of this article (for both commercial and non-commercial purposes), subject to full attribution to the original publication and authors. The full terms of this license may be seen

at: $\underline{\text { http://creativecommons.org/licences/by/4.0/legalcode }}$

Vol. 9, No. 3, 2019, Pg. 875 - 883

http://hrmars.com/index.php/pages/detail/IJARBSS

JOURNAL HOMEPAGE

Full Terms \& Conditions of access and use can be found at http://hrmars.com/index.php/pages/detail/publication-ethics 




\title{
Factors Stimulating Students to Venture into The Field of Entrepreneurship Towards Producing Entrepreneurs Among University Students
}

\author{
Muhammad Bazlan Mustafa \\ Mohammad Nasir Bistamam, Mohammad Aziz Shah Mohamed Arep, Nor Azrin Bin Md Latip, \\ Samsiah Mohd Jais \\ Faculty of Human Development, Sultan Idris Education University, Malaysia
}

\begin{abstract}
This study aims to identify the factors that stimulate students to get involved in the field of entrepreneurship towards producing entrepreneurs among Bachelor Degree students from Universiti Pendidikan Sultan Idris (UPSI). Information was obtained through the questionnaire involving 756 students following the Bachelor Degree in Education and the Non-Education Bachelor Degree in UPSI. A set of questionnaire was used to identify information about oneself and the factors that stimulate the students to venture into entrepreneurship. The study results show that most students have high level of these factors -attitude and need for achievement whereas moderate level for interest, university, intention behind entrepreneurship, readiness, obstacle and low for background. The need for skills and development of entrepreneurship required by UPSI students would be the basic course in entrepreneurship, and the support from the university, provision of capital assistance and the infrastructure such as preparing business space and continuous hands-on courses will also spur the students to venture into entrepreneurship. This study also shows that the majority of UPSI students are interested, have positive attitude and the desire to become entrepreneurs.
\end{abstract}

Keywords: Stimulating factors, Entrepreneurship, Entrepreneurs

\section{Introduction}

The issue of unemployment among graduates is not new and it has become a cause for concern for the country. The issue of unemployment is prevalent as universities produce thousands of graduates every year. Graduates' skills and knowledge cannot be used to contribute to the national development. If the increase in the number of the graduates is not equipped with job opportunities which are consistent with their qualification and field of study, it can make people assume that high education in a country is not really successful in producing labour that matches the market requirements. The inconsistency of the offering and request in the graduates' labour market has created a lot of issues not only in terms of the role of higher learning institutes and the study 
programs offered but also in terms of the graduates produced. Thus, graduates' involvement in the field of entrepreneurship is able to curb and reduce the issue of unemployment. The field even offers job opportunities to other people. Therefore, students at universities have to be encouraged or motivated to enter entrepreneurship

The study by Zairon, Noor Afizah and Elyn (2017) shows that entrepreneurship values cannot be inherited and influenced by family background. It can be shaped and depend on the combination of experience and knowledge obtained by the student himself or herself. Meanwhile, the study by Haider (2013) shows that family background gives a significant impact on students' entrepreneurial ability and potential. The motivation and capacity to start one's own business for students whose family has embarked upon their own business are also higher than those without such families. Majumdar and Varadarajan (2013) state that the tendency to become an entrepreneur is not influenced by gender but depending more on other factors like creativity, motivation and awareness.

The study by Mohd. Hassan (2007) shows that the majority of entrepreneurs agreed that the factors of motivation, attitude, and skills are the most important factors in influencing them to become an entrepreneur whereas the factor of background did not really influence them to engage themselves in entrepreneurship. The findings of the study by Farliyanna and Nor Aishah (2017) show that the attitude of an entrepreneur, the source of motivation and self-efficacy have a significant, moderately positive relationship with the level of aspiration of entrepreneurship. Salmianti (2013) shows that the factor of motivation is the one main factor that influences students to become inclined to venture into entrepreneurship. The study by Francis et. al. (2015) establishes that the behavioural factors like attitude, subjective norm, and presumed behavior have a significant impact on the entrepreneurship intention. Other than that, the perceived positive image towards entrepreneurs and an obstacle in the form of financial assistance have also impacted their intention. The study by Amran, et. al. (2013) shows that confidence is the strongest variable that that has a direct influence towards entrepreneurial intention. Attitude also has a significant influence towards entrepreneurial intention. Other than that, male graduates with working experience are found to have higher entrepreneurial intention.

Majumdar and Varadarajan (2013) have proven that the tendency to become the up and coming entrepreneurs is not influenced by the factor of gender but depends on other factors like creativity, motivation and awareness. Holienka, Holienkova and Gal (2015) find that students from business administration program have noted the highest tendency towards entrepreneurship for all six aspects being studied, compared to students from other programs. This study further provides evidence on the importance of entrepreneurship education as it can help instill the spirit of entrepreneurship among university students.

Based on the studies done, factors of family background, creativity, motivation, attitude, skills, intention behind entrepreneurship, entrepreneurship education have all been associated. Based on the literature review, this study chooses the factors aforementioned as those that encourage UPSI students to venture into entrepreneurship towards producing entrepreneurs among university students. Through these factors, various strategies can be planned by the parties held responsible in the development of entrepreneurs to conduct various programs deemed suitable for university students. 
INTERNATIONAL JOURNAL OF ACADEMIC RESEARCH IN BUSINESS AND SOCIAL SCIENCES

Vol. 9, No. 3, March, 2019, E-ISSN: 2222-6990 @ 2019 HRMARS

\section{Problem Statement}

The government has allocated a big amount of money every year in developing higher education in Malaysia. Other than the financial allocation, the increasing number of Higher Learning Institutes (IPT) is also a crucial indicator to the effort of preparing more opportunities to the residents to obtain higher education.

However, unemployment and the difficulty in getting a job among graduates have become an issue that has created a negative perception towards the higher learning development policy in this country. The Higher Learning Department's Graduate Detection Study, Minister of Education Malaysia shows that in 2016 the number of graduates produced was 238,187 people.

Public universities produce a total of 123,639 graduates followed by graduates from private higher learning institutes totalling 93,191 graduates, polytechnic (23,318 graduates), community college (7,317 graduates) and those from higher learning institutes lain totalling 1,814 graduates. All in all, 56.5\% graduates stated that they have worked during their convocation ceremonies. Meanwhile, $14.5 \%$ stated that they have furthered their studies to a higher level, $4.0 \%$ were waiting for job placement and $2.3 \%$ were trying to improve their skills. The remaining $22.7 \%$ were still not working when this study was conducted.

Universiti Pendidikan Sultan Idris (UPSI) is also facing the same problem. Although UPSI is an education university, there are also non-education programs offered by the university. Meanwhile, students following the education program are students in the open market where they are no longer necessarily offered the job as teacher in Ministry of Education schools. A UPSI graduate detection study (2016) shows that only 3199 people (57.3\%) become teachers, 69 (1.2\%) further their studies, 1592 (28.5\%) are not working, 27 (0.5\%) become entrepreneurs, 146 (2.6\%) do their own businesses, 324 (5.8\%) work in the private sector 222 (4\%) become administrators.

Employers who tend to choose more experienced workers have also contributed to the unemployment. New graduates are not given the chance to try because most employers opine that they do not want to suffer from any losses because of this lack of experience. For employers, experience is crucial to facilitate work (Che Mohd Zulkifli dan Shanmuganathan Rajoo, 2016). Another contributing factor is that the graduates tend to be choosy in selecting the job for themselves. This is because they are still looking for the 'right' jobs and which promises income that fits their academic qualifications.

The UPSI Graduate Detection study (2016) shows that 39,439 graduates (72.9\%) stated that they were still looking for jobs, 3,885 graduates (7.2\%) wanted to have a break, 2,313 graduates (4.3 percent) were waiting for placement, 2,892 graduates (5.3\%) had a responsibility towards their families, 1.452 graduates $(2.7 \%)$ stated that the work offered was not suitable with their qualifications, 1,363 graduates $(2.5 \%)$ chose not to work, 480 graduates $(0.9 \%)$ were not interested to work, 328 graduates $(0.6 \%)$ lack the self-confidence to start working, 418 graduates $(0.8 \%)$ had health issues and 117 graduates ( 0.2 percent) were reluctant to move to another place. The study by Gunadevi K. Jeevi Subramaniam and Raja Nor Safinas Raja Harun (2013) shows that students admitted that there is a lack of industrial training in communication skills especially when dealing with customers and employers stress on the importance of communicating with customers in English.

As the working opportunity in the public sector and the private sector is very limited, university graduates have to be independent and able to choose their own career. Entrepreneurship 
career is successful in creating job opportunities and further reduce the rate of unemployment among the citizens in a country (Rosdi, 2000; Shane \&Venkataraman, 2000). Being an entrepreneur means escaping from the chains of unemployment. This means that an entrepreneur is able to prove that this group does not need to depend on the job offers in both the public or the private sector. The effort success of an entrepreneur will become an example and aspiration to other people. Next, a successful entrepreneur will develop activities of entrepreneurship by creating more job opportunities and more societal needs get to be provided.

Thus, this study is implemented among UPSI students to identify if the field of entrepreneurship becomes their choice. Based on the literature review, an appropriate stimulating factor is very important for a student to embark upon the field of entrepreneurship. This is due to unemployment issues that arise among UPSI's students need to be resolved immediately. According to UPSI graduate detection study (2016), only 27 (0.5\%) of them become an entrepreneur and 146 $(2.6 \%)$ do their own businesses. Studies on entrepreneurship interest already conducted among UPSI students, however, a large-scale study involving both groups of students, educational and noneducational undergraduate students have not yet been conducted. Therefore, studies related to this among students doing Bachelor Degree in Education in Universiti Pendidikan Sultan Idris are crucial to be done.

\section{Research Objectives}

This study is conducted to identify factors that urge students of UPSI to venture into entrepreneurship. The factors identified are family, attitude, university, the need for achievement, the intention behind entrepreneurship, readiness and obstacle.

\section{Methodology}

This study is a survey, aiming to get as much information as possible in relation to entrepreneurship through a population, or specifically UPSI students. A survey was conducted using a questionnaire. The study subject are students following the Education Bachelor Degree program and Bachelor Degree at UPSI. This study is done on Third Year students and some are in their Fourth Year. All nine faculties at UPSI are involved in this study. Third Year students were chosen as the respondents of this study. The current work requires the respondents who are deemed mature and have undergone the life process as university students. If they want to go into entrepreneurship, they have prepared themselves and use various facilities throughout their studies in UPSI.

The stratified sampling procedure is also adopted in this study. The study divides the population into two sub-populations. They are Bachelor Degree in Education and Bachelor Degree. The second sub-sample is gender. Then, the study respondents were selected through the random sampling approach where the subject in the population has the same probability to be chosen. A set of questionnaires comprising demographic and stimulating factors for students to venture into entrepreneurship which are background, attitude, interest, university, need for achievement, entrepreneurial intention, readiness and obstacle. The questionnaire was constructed by Muhammad Bazlan et. al (2018) containing 64 questions. The validity of the item was measured through the relationship or the correlation between the total score and the score of each item as proposed by Anastasi and Urbina (1997) and also by Ary et al. (2006). The Pearson Correlation analysis 
method was done between the score of every item and the total score according to the construct in question. The correlation coefficient value used to measure the validity of the questionnaire is more than.40 as suggested by Ary et al. (2006). To measure the reliability of the measuring tool, the Cronbach Alpha technique was adopted. This method is a popular test and it is often used in measuring the consistency. The study finding shows that the Cronbach Alpha coefficient for the questionnaire is 0.967 .

\section{Findings}

756 respondents had answered the questionnaire distributed. According to Table 1, most of the respondents in this study comprise of female students totaling 548 people (72.5\%) and 208 (27.5\%) are male students. 441 people (58.3\%) are students of Bachelor Degree in Education and 315 more (41.7\%) are students from other Bachelor Degree programs. The descriptive analysis process was done on every variable of the stimulating factors namely family, attitude, interest, university, need for achievement, intention behind entrepreneurship, readiness and obstacles.

The descriptive analysis done shows that most students have shown factors of interest, university, intention behind entrepreneurship, readiness and obstacle at moderate level. The highest number of students with high level of factors is evident on factors of attitude and the need for achievement. Nonetheless, most students show low level in the factor of family background in the sectors of business or entrepreneurship.

Table 1: The descriptive statistics for other stimulating factors namely background, attitude, interest, need for achievement, intention behind entrepreneurship, readiness and obstacles.

\begin{tabular}{lcccccc}
\hline \multirow{2}{*}{ Stimulating Factor } & \multicolumn{2}{c}{ Low } & \multicolumn{2}{c}{ Moderate } & \multicolumn{2}{c}{ High } \\
\cline { 2 - 7 } & $f$ & $\%$ & $f$ & $\%$ & $f$ & $\%$ \\
\hline Family & 379 & 50.1 & 238 & 31.5 & 139 & 18.4 \\
Attitude & 9 & 1.2 & 372 & 49.2 & 375 & 49.6 \\
Interest & 65 & 8.6 & 377 & 49.9 & 314 & 41.1 \\
University & 51 & 6.7 & 364 & 48.1 & 341 & 45.1 \\
Need for achievement & 8 & 1.1 & 284 & 37.6 & 464 & 61.4 \\
Entrepreneurial Intention & 55 & 7.3 & 517 & 68.4 & 184 & 24.3 \\
Readiness & 134 & 17.7 & 424 & 56.1 & 198 & 26.2 \\
Obstacles & 261 & 34.5 & 420 & 55.6 & 75 & 9.9 \\
\hline
\end{tabular}

\section{Conclusion and Recommendation}

This study shows that the intention behind entrepreneurship cannot be inherited through family members but it can be shaped through the student's own experience and knowledge. The basic knowledge about entrepreneurship obtained through education can trigger students' spirit to go into the world of entrepreneurship. The attitude of being able to influence individuals in making decisions in the field of endeavor is key. This study shows that UPSI students have a positive attitude towards entrepreneurship. The awareness towards the role, contribution and importance of the field of 
INTERNATIONAL JOURNAL OF ACADEMIC RESEARCH IN BUSINESS AND SOCIAL SCIENCES

Vol. 9, No. 3, March, 2019, E-ISSN: 2222-6990 @ 2019 HRMARS

entrepreneurship to self-empowerment has strengthened the students' attitude towards entrepreneurship.

The interest in entrepreneurship is a motivating factor that influences one to continue his or her entrepreneurship effort. The study result shows that UPSI students who have shown interest in venturing into entrepreneurship are at moderate level. This shows that UPSI students still have the intention to work under other people when they finish their studies. The study outcome establishes that the university factor influences students to venture into entrepreneurship where most students get moderate and high scores. This study shows that campus infrastructure is able to influence students' interest to go into entrepreneurship. A conducive university environment is an important element in influencing the entrepreneurship intention among students.

The results of the study show that the majority of the students have high need for achievement. Individuals with high level of need for achievement tend to be more motivated, competitive and wise enough in using opportunities available in a business. This shows that students have high internal motivation to achieve success and further urges them to go into the world of entrepreneurship. The study also shows that the majority of the students have moderate level in entrepreneurship intention. This is a very important element that can shape students' positive behavior to start a business. This is because they are also influenced by the factor of readiness and obstacles to go into entrepreneurship. Most students obtain average scores for the factors of readiness and obstacles. It demonstrates that UPSI students have the readiness to venture into entrepreneurship.

Other than that, this study finds that most of the students agree with the factors of obstacle that cause the students to lack the interest in entering the world of entrepreneurship. This is because they are still hesitant about choosing entrepreneur as their career, about their lack of knowledge in their business world, about the fact that they worry for the uncertainty of their income, that they fear for competition and they are afraid to face the risk of failing in their business. It is not common for the graduates to embark upon the field of entrepreneurship because they do not have the interest, they do not want to take the risk, they have the mentality of working under other people, they want to first and they are also not confident about the field of entrepreneurship. Thus, obstacles have to be given attention in formulating strategies so that students can be drawn into venturing into entrepreneurship after they finish their studies.

As the conclusion, according to Table 1, main factor that encouraging students to venture into entrepreneurship was need for achievement, followed by attitude, university, interest, readiness, entrepreneurial intention and family. The obstacles factor is still low and is not the main factor in preventing students from entrepreneurship. Therefore, two factors which were readiness and entrepreneurial intention including family support should be addressed by certain parties in encouraging students to venture into entrepreneurship.

It is hoped that this study can offer a contribution and benefit to various parties like students, universities and Ministry of Education Malaysia in helping to increase students' involvement in trying to go into entrepreneurship and making it as a career. The study finding also shows that UPSI students do intend to start their own businesses. Thus, they need to be equipped with the skills, experiences and exposure of entrepreneurship other than encouraging and drawing students' interest to get involved in entrepreneurship activities in the university. 
The result further shows that the university supports UPSI students in embarking into entrepreneurship. However, it is suggested that the university should take more encouraging steps and support students if they want to try entrepreneurship. The traditional teaching and learning approach also need to be changed from active learning examination-based learning. Thus, the teaching method has to be instilled with learning activities such as learning by doing to give a better impact on students' understanding. Activities like knowledge sharing, experience, as well as forum with entrepreneurs and successful business people will ignite the sharing of ideas and the transfer of experiences based on entrepreneurship. Lastly, parental support is crucial as a motivator for entrepreneurs. The university needs to involve parents to plan and help their children to venture into entrepreneurship.

\section{Corresponding Author}

Name: Muhammad Bazlan Bin Mustafa

Affiliation: Sultan Idris Education University

Country: Malaysia

Email Id: bazlan@fppm.upsi.edu.my

Address: Sultan Idris Education University,

Faculty of Human Development

35900, Tanjong Malim, Perak.

Acknowledgement: This work was financially supported by the Universiti Pendidikan Sultan Idris under Universiti Research Grant (2017-0268-107-01).

\section{References}

Rasli, A. M., Khan, S. R., \& Malekifar, S. (2013). Factors affecting entrepreneurial intention among graduate students of Universiti Teknologi Malaysia. International Journal of Business and Social Science, 4(2), 182-188.

Anastasi, A., \& Urbina, S. (1997). Psychological testing (7th ed.). Upper Saddle River, NJ, US: Prentice Hall/Pearson Education.

Ary, D., Jacobs, L. C., Razavieh, A., \& Sorensen, C. (2006). Introduction to research in education. Wadsworth: Cengage Learning.

Alumni Detection Research Data (2016). Alumni.upsi.edu.my/image/Data-2016.png. Retrieved on 10 September 2017.

Francis C., Hiram T., Syed Ridhwan Alsree \& Cheah J. H. (2015). Factors affecting entrepreneurial intention of Malaysian university students. In Conference Business Management Research II (CBMR II 2015), 22 December 2015. School of Business Management, Universiti Utara Malaysia, Sintok, Kedah, Malaysia.

Gunadevi, K., Subramaniam, J. \& Harun, R. N. S. R. (2013). The ability of the polytechnics marketing student in using good English oral communication skills during industrial training. English for Specific Purposes World, 14(39). 
Haider, M. I. (2013). Impact of business education and family background on entrepreneurial potential. International Journal of Innovative and Applied Finance. Tersedia di SSRN: https://ssrn.com/abstract=2759169.

Holienka, M., Holienkova, J., \& Gal, P. (2015). Entrepreneurial characteristics of students in different fields of study: A view from entrepreneurship education perspective. Acta Universitasis Agriculturae et Silviculturae Mendeliane Brumesis, 63(6), 1879-1889.

Malaysian Ministry of Higher Education (2017). Detection Research of Higher Educational Institute's Graduates. Putrajaya: Malaysian Ministry of Higher Education.

Majumdar, S. \& Varadarajan, D. (2013). Students' attitude towards entrepreneurship: Does gender matter in the UAE? Foresight, 15(4), 278-293.

Hassan, M. (2007). Factors that encouraged students and alumni of Universiti Teknologi MARA Malaysia to venture into entrepreneurship field. Skudai: Penerbitan UTM.

Mutalib, S. (2013). Survey on Entrepreneurship Inclination among students in higher educational institutes. Journal of Techno-Social, 5(1), 1-13.

Shane, S., \& Venkataraman, S. (2000). The promise of entrepreneurship as a field of research. Academy of Management Review, 25, 217-226.

Mustapha, Z., Atan, N. A. \& Ridzwan, E. M. (2017). The surge of entrepreneurship values among polytechnic students through i-Smart program. Advanced Journal of Technical and Vocational Education, 1(1), 291-300. 